\title{
Traditional knowledge and uses of the Caryocar brasiliense Cambess. (Pequi) by "quilombolas" of Minas Gerais, Brazil: subsidies for sustainable management
}

\author{
L. C. L. Pinto ${ }^{a}$, L. M. O. Morais ${ }^{a}$, A. Q. Guimarães ${ }^{a}$, E. D. Almada , \\ P. M. Barbosa and M. A. Drumond ${ }^{a}$ *

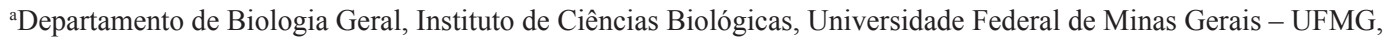 \\ Bloco I3, Avenida Antônio Carlos, 6627, Pampulha, CEP 31270-901, Belo Horizonte, MG, Brazil \\ bLaboratório de Estudos Bioculturais, Universidade do Estado de Minas Gerais - UEMG, \\ Avenida São Paulo, 3996, Vila Rosário, CEP 32400-000, Ibirité, MG, Brazil \\ *e-mail: dodoradrumondbh@gmail.com
}

Received: November 4, 2014 - Accepted: February 9, 2015 - Distributed: May 31, 2016

(With 1 figure)

\begin{abstract}
Local knowledge of biodiversity has been applied in support of research focused on utilizing and management of natural resources and promotion of conservation. Among these resources, Pequi (Caryocar brasiliense Cambess.) is important as a source of income and food for communities living in the Cerrado biome. In Pontinha, a "quilombola" community, which is located in the central region of State of Minas Gerais, Brazil, an ethnoecological study about Pequi was conducted to support initiatives for generating income for this community. Data were collected through semi-structured interviews, participant observation, and crossing. The most relevant uses of Pequi were family food (97\%), soap production (67\%), oil production (37\%), medical treatments $(17 \%)$, and trade $(3 \%)$. Bees were the floral visitors with the highest Salience Index $(\mathrm{S}=0.639)$. Among frugivores that feed on unfallen fruits, birds showed a higher Salience $(\mathrm{S}=0.359)$ and among frugivores who use fallen fruits insects were the most important $(\mathrm{S}=0.574)$. Borers (folivorous caterpillars) that attack trunks and roots were the most common pests cited. According to the respondents, young individuals of Pequi are the most affected by fire due to their smaller size and thinner bark. Recognition of the cultural and ecological importance of Pequi has mobilized the community, which has shown interest in incorporating this species as an alternative source of income.
\end{abstract}

Keywords: Cerrado, traditional communities, ethnoecology, income.

\section{Conhecimento tradicional e usos de Caryocar brasiliense Cambess. (Pequi) por quilombolas de Minas Gerais, Brasil: subsídios para o manejo sustentável}

\begin{abstract}
Resumo
O conhecimento local acerca da biodiversidade vem sendo utilizado em pesquisas voltadas ao uso e manejo de recursos naturais aliados à conservação. Entre estes recursos, destaca-se o Pequi (Caryocar brasiliense Cambess.) devido à sua importância econômica e alimentar para comunidades que vivem no Cerrado. No quilombo de Pontinha, localizado na região central do estado de Minas Gerais, um estudo etnoecológico sobre o Pequi foi desenvolvido, a fim de subsidiar iniciativas de geração de trabalho e renda para esta comunidade. Informações foram obtidas por meio de entrevistas semiestruturadas, observação participante e travessia. Alimentação familiar (97\%), produção de sabão (67\%), produção de óleo (37\%), tratamento medicinal (17\%) e comércio (3\%) foram os principais usos do Pequi citados pelos comunitários. Abelhas foram os visitantes florais com maior Índice de Saliência $(S=0,639)$. Dentre os frugívoros que se alimentam de frutos não caídos, as aves apresentaram maior Saliência $(S=0,359)$ e os insetos foram os mais importantes frugívoros entre os que utilizam frutos caídos $(S=0,574)$. Brocas, lagartas folívoras e que atacam troncos e raízes foram as pragas mais citadas. Os indivíduos jovens de Pequi são, segundo os entrevistados, os mais afetados pelo fogo devido ao menor porte e por ter a casca menos espessa. O reconhecimento da importância cultural e ecológica do Pequi tem mobilizado a comunidade, que demonstra interesse em fazer dessa espécie uma alternativa de renda.
\end{abstract}

Palavras-chave: Cerrado, comunidades tradicionais, etnoecologia, renda. 


\section{Introduction}

The study area is located in the Cerrado biodiversity hotspot, a biome that covers approximately $22 \%$ of Brazil (Ratter, 1997; Mittermeier et al., 2004). In addition to its biological importance, Cerrado is home to a diverse range of traditional communities that embody great knowledge about its resources. Indigenous peoples, "quilombolas", "vazanteiros", "retireiros", "geraizeiros" and woman breakers ("quebradeiras de coco") are the main ethnically differentiated groups in this biome (Barbosa et al., 1990; Brasil, 2004). These and other rural communities obtain part of their income through networks of collection, processing, and trade of sociobiodiversity products (Pozo, 1997; Silva and Tubaldini, 2013).

The Pequi tree (Caryocar brasiliense Cambess., Caryocaraceae) (Medeiros and Amorim, 2015) has great economic and subsistence values for many communities living in the Cerrado (Araujo, 1995; Vieira et al., 2006; Sano et al., 2008; Afonso and Ângelo, 2009; Assunção, 2012, Santos et al., 2013). Pequi fruits can be consumed fresh or as jams, jellies, liqueurs, creams and oils (Germano et al., 2007; Carvalho, 2008) and their leaves are also used in folk medicine for treating respiratory diseases (Rodrigues and Carvalho, 2001; Germano et al., 2007; Monteles and Pinheiro, 2007) or manufacturing cosmetics products (Oliveira et al., 2008; Pianovski et al., 2008). In addition to the ethnobotanic and ethnoecological investigations with C. brasiliense, other studies show anti-inflammatory and antioxidants properties of the oil extracted from the Pequi pulp (Roesler et al., 2008; Aquino et al., 2011).

In northern Brazil the species Caryocar villosum (Albu.) Pers., popularly known as Piquiá, has a wide range of culinary, commercial, and medicinal uses, being indicated for treating inflammatory and respiratory diseases (Rios et al., 2001). In this sense, studies in Tapajós National Forest showed analgesic and anti-inflammatory properties of this species, both recognized by the forest dwellers and verified by pharmacological investigations undertaken in this protected area (Galuppo, 2004). Caryocar coreaceum Wittm., another species of northeastern Brazil, is used for culinary, economic, and medicinal purposes (Gonçalves, 2008; Saraiva et al., 2011, Sousa-Júnior et al., 2013). In Chapada do Araripe, (Ceará State), in addition to the uses already mentioned, the fruit shell of $C$. coreaceum is used as animal fodder (Sousa-Júnior et al., 2013).

Many traditional communities have associated the use of natural resources with their conservation, since they have direct dependence on these resources for their economic and social development (Diegues and Viana, 2004; Pedroso-Júnior and Sato, 2005, Lima, 2008; Oliveira, 2009; Lima et al., 2012, Sousa-Júnior et al., 2013). An increasing number of studies take into account the value of the vast knowledge of rural communities obtained by practice and observations since this knowledge contributes to the collective definition of the best conservation strategies and sustainable use of resources (Berkes et al., 2000; Hanazaki, 2003; Donovan and Puri, 2004; Figueiredo et al.,
2006; Lima, 2008; Oliveira, 2009; Schmidt et al., 2007; Sousa-Júnior et al., 2013; Drumond et al., 2013).

A large number of ethnobotanic studies with brazilian Afrodescendant communities have been reviewed by Albuquerque (1999). Other studies specially developed with "quilombolas" communities were recognized as important sources of information about Brazilian biodiversity, as well for the conservation of biomes such as the Atlantic Rain Forest (Barroso et al., 2010; Crepaldi and Peixoto, 2010; Almada, 2012; Adams et al., 2013), the Amazonian (Oliveira et al., 2011), and the Cerrado (Franco and Barros, 2006; Massarotto, 2009; Cezari, 2010; Viana, 2013). Besides being source of basic subsistence, biodiversity is crucial for the "quilombolas" health care, spiritual practice, and to providing material for infrastructure, technology, ornaments, fuel, and source of alternative income (Franco and Barros, 2006; Massarotto, 2009; Barroso et al., 2010; Crepaldi and Peixoto, 2010; Cezari, 2010; Viana, 2013).

The "quilombola" community of Pontinha, located in central region of the State of Minas Gerais, is closely related on Cerrado's biological resources for income and the reproduction of its ways of living (Morais et al., 2013). Among these resources, the extractivism of a giant earthworm ("minhocuçu”) Rhinodrilus alatus (RIGHI 1971) is one of the most important activities for the "quilombo" dwellers. Nevertheless, the management of this species requires restrictions, especially with respect to its extraction during the breeding period, which occurs in the rainy season from October to February (Drumond et al., 2013). However, suspension of the extraction is more feasible if combined with promoting and developing an alternative source of income during this time of year.

The C. brasiliense species is abundant in Pontinha's territory and the fruit production overlap with minhocuçu's breeding period, in this context we seek to study local knowledge about Pequi to contribute to the assessment of the feasibility of its use as an alternative income source for the community.

\section{Material and Methods}

\subsection{Study area}

The "quilombo" of Pontinha has 774 hectares and approximately 200 households (Sabará, 2001). This territory is situated in the central region of the State of Minas Gerais, in Brazil, and is $18 \mathrm{~km}$ from the municipality of Paraopeba (Figure 1). This area has an important remnant of Cerrado that, although modified, contrasts with the surroundings, where pastures and monocultures of Eucalyptus and Pinus predominate.

\subsection{Data collection and analyses}

Ethnoecological information was gathered through semi-structured interviews of 30 residents and open interviews of 20 residents during the months of November 2012 to July 2014. The use of these tools allowed the research team more flexibility to deepen into topics that emerged spontaneously during the dialogue with 


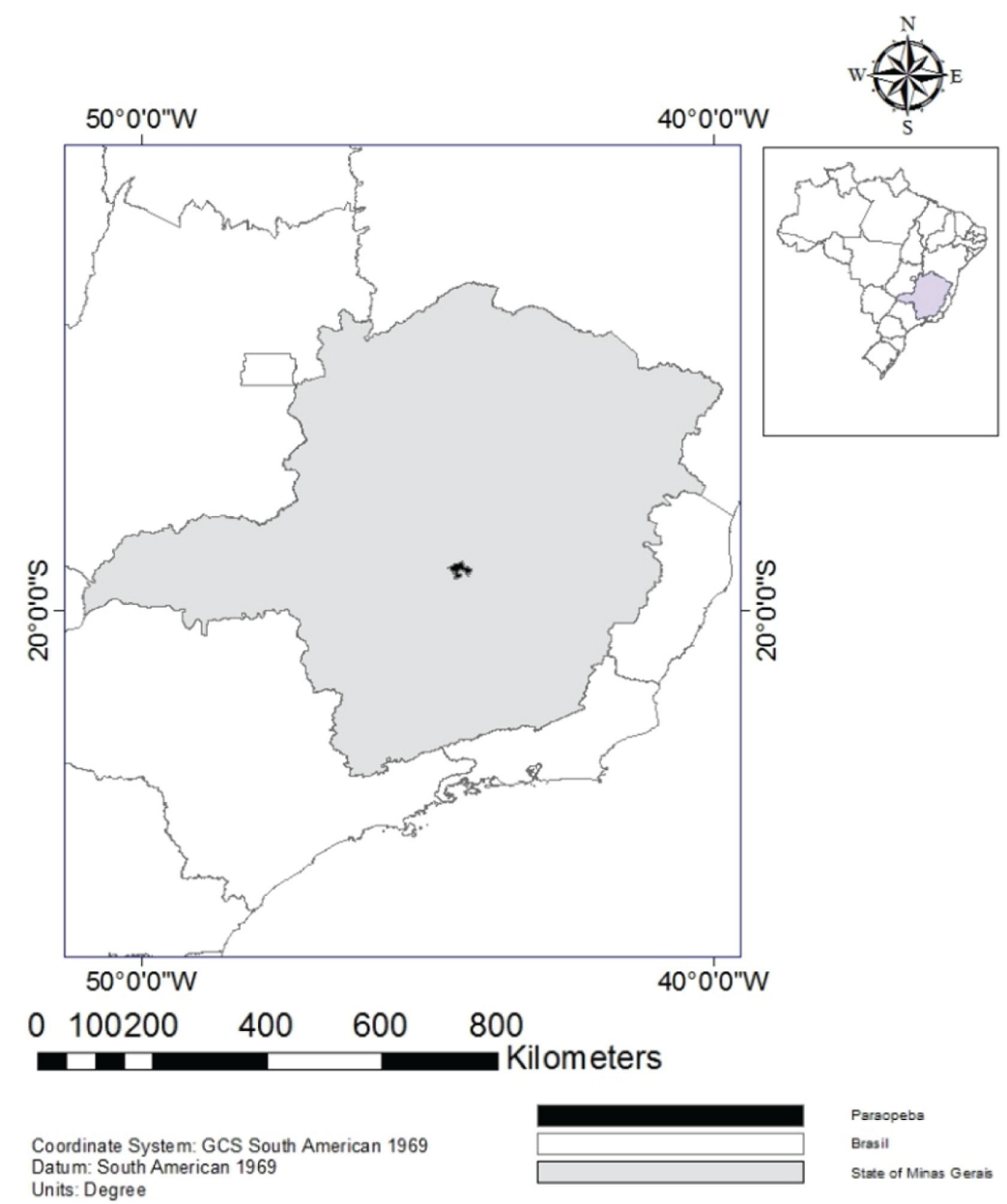

Figure 1. Municipality of Paraopeba in the central region of state of Minas Gerais, Brazil, where the "quilombola" community of Pontinha is located.

the community (Albuquerque et al., 2010). Opened and semi-structured interviews support the establishment of confidence relationships between the researchers and community (Drumond et al., 2009). The choice of first respondent was non-probabilistic and intentional (Bernard, 2006; Albuquerque et al., 2010) because the researchers had been in contact with the community for over 10 years and established relationships of trust that enabled this selection. After the first contact, the remaining respondents were indicated using the snowball tool (Bailey, 2008).

The interview addressed the seasonal dynamics of Pequi, floral visitors, frugivores and parasites, impacts of fire on the species, and uses of this species. The information on frugivory and floral visitors was obtained from a free list (Bernard, 1988; Albuquerque et al., 2010). Participant observation was also used as residents worked during routine activities involving the Pequi, such as the gathering of fruit in the Cerrado and backyards and uses of the fruit to prepare meals and recipes. In crossing (Drumond et al., 2009) additional information was obtained from reports given by four residents. Triangulation (Drumond et al., 2009) allowed better evaluation of the data obtained.

The resultant information regarding traditional knowledge about the Pequi tree was shared with the local community in a workshop with 11 residents. These results were documented in a video that was discussed with 21 participants in another meeting, where it was possible to legitimize the information obtained.

Smith's Salience Index (Puri and Vogl, 2005; Morais and Silva, 2010) was calculated using Anthropac 4.0 program. A higher Index value (from 0 to 1 ) indicate a greater consensus among the respondents on the topic studied (Puri and Vogl, 2005). Semi-structured and open interviews, participation observation, and crossing data were analyzed qualitatively.

The present study was approved by the Ethics Committee of the Federal University of Minas Gerais $\left(\mathrm{n}^{\mathrm{o}}\right.$ 0388812.2.000.5149). The interviews were always preceded by an explanation about the purpose of work and a permission were given by a Term of Informed 
Consent ("Termo de Consentimento Livre e Esclarecido"). Recordings, field notes, and photographs were archived at the Laboratory of Socio-Ecological Systems of the Federal University of Minas Gerais (Universidade Federal de Minas Gerais).

\section{Results and Discussion}

Among the respondents, all were born in the Pontinha community, $19(63 \%)$ were women, $11(37 \%)$ were men, and their ages ranged between 17 and 83 years. The primary uses of Pequi detailed by the respondents were as follows: family food (97\%), soap production (67\%), oil production $(37 \%)$, medical treatment $(17 \%)$, and trade $(3 \%)$.

In the category "family food", the following uses of Pequi were included: prepared with rice and chicken, cooked with salt, sweet, shaken with milk and sugar ("Chocolate"), liquor, nut (consumed fresh and the sweet form), with sweet rice, with cheese, cake, and popsicle ("chup chup").

According to the respondents, the choice of the fruit depends on the purpose of its use, and it is evaluated by the color, flavor, and quantity of the pulp, as well as by the number of seeds and the appearance of the shell. The Pequi trees that are known for the quality of their fruits are identified by reference to the house where the resident lives. The bitter fruits are locally called "marujentos" or rancid and are only used to make soap. By contrast, the sweet fruits with more pulp are called "fleshy" and are used in cooking.

The manufacture of soap from the flesh and kernel of Pequi (inner mesocarp) was mentioned by $63 \%(n=19)$ of respondents and also was recorded during the crossing. The soap has a granular appearance and dark color and is only for domestic use, which is in accordance to what was reported and demonstrated by one of the interviewees. Although the use of Pequi for the production of oil was reported in $37 \%$ of the interviews ( $n=11$ ), the majority of respondents were unaware of the methods of extraction and preparation, and only one person indicated that he knew how to extract the oil from the Pequi pulp. Oliveira (2009) and Lima (2008) reported the extraction of oil from both Pequi pulp and nuts for use in cooking and traditional medicine in communities in northern Minas Gerais. These products, according to Afonso and Ângelo (2009), have a high market value compared with the "in natura" fruit, creams, and sweets. In Ceará State, Caryocar coriaceum fruits are classified by extractivists according to their size (big or small). The big fruits are more valued by buyers, and the small fruits are destined for oil production (Sousa-Júnior et al., 2013).

Pequi leaves are used for medicinal purposes, and the infusion of young leaves (shoots or "sprouts") is used to combat flu and abdominal pain and "help the kidneys." Rural communities in Lavras and Rio Pardo de Minas municipalities, both located in State of Minas Gerais, use Pequi nut and pulp oil to treat respiratory diseases such as bronchitis and asthma (Rodrigues and Carvalho, 2001; Oliveira, 2009).

Processed products such as Pequi liqueur, sweets, and soap have been sold locally in the past, and in most cases, sold to order. However, this practice was not observed during the present study. Other uses not mentioned by the participants, including the use of the Pequi shell as an alternative feed for cattle and fish and for manufacturing dark-brown dyes, have been reported in the literature (Bonfá et al., 2009; Oliveira and Scariot, 2010), and there may be additional alternative uses in the Pontinha community.

Among the flower visitors, bees had the highest Salience $(\mathrm{S}=0.639)$ and were categorized by different local names (Table 1). Hummingbirds were also identified as important floral visitors both at Pontinha $(\mathrm{S}=0.261)$ and by Melo (2001), in a study conducted in Distrito Federal, in the central Brazilian region. The presence of floral visitors was related to the pursuit of pollen or honey, sweet liquid, sugar, and nectar, and their categorization indicates a similar perception for the type of use, although with distinct terminology.

The light-colored flowers of the Pequi tree are associated with a strong odor and nectar production at dusk, which suggests that the primary pollinator is bats (Oliveira et al., 2008). The importance of bats as pollinators of Pequi trees is recognized in the literature (Melo, 2001; Oliveira et al., 2008; Carvalho, 2008) and by the Pontinha respondents, although the Salience Index was low for bats $(\mathrm{S}=0.017)$.

Answers related to frugivory were discriminate into two categories: a) animals that feed on fallen fruits and b) animals that feed on unfallen fruits. Frugivores were also grouped according to their respective Salience Indices (Table 2).

The number of animals mentioned that feed on fallen fruits $(n=23)$ was higher than those that feed on unfallen fruits $(n=13)$. According to Oliveira and Scariot (2010), the Pequi fruits complete ripening and have a greater concentration of vitamins and proteins three days after the natural fall, and these characteristics can attract more frugivorous species; in addition, there is greater exposure of the yellow pulp that covers the seed after the fruits fall.

The values of the Salience Indices for animals (Table 2) that feed on unfallen fruits indicate a greater importance of magpies, parrots ("maritaca" and "papagaio," respectively), bats, and passerine birds. As for the fallen fruit on the ground, ants showed a higher Salience Index $(\mathrm{S}=0.527)$. Rheas, seriemas, parrots, crows, carcara hawks, agoutis, deer, opossum, and caterpillars are recognized in the literature as frugivores of $C$. brasiliense and possible primary dispersers (Gribel, 1986; Carvalho, 2008; Oliveira and Scariot, 2010). Ants, termites, and beetles can also be effective in removing the pulp and burying the seeds, which may favor germination (Oliveira, 2009; Zardo and Henriques, 2011).

The most cited flowering period was from August to October, and the most cited fruiting period was from October to January. The Pequi fruits begin to emerge 
Table 1. Values of cultural consensus (S) for the floral visitors of the Pequi tree (Caryocar brasiliense) as cited by respondents from the Pontinha community, Minas Gerais.

\begin{tabular}{lccc}
\hline & Common name & Folk name & Salience (S) \\
\hline BIRDS & & 0.261 \\
& Hummingbird & Beija-flor & 0.261 \\
& Passerine & Passarinho & 0.025
\end{tabular}

INSECTS

BEES
Bee
European bee
Bumblebee
Stingless bees
Bumblebee
Bumblebee
Orchid bee
Stingless bees

MAMMALS

DO NOT KNOW
Bats

OTHER INSECTS
Wasp
Beetle

$\begin{array}{cc} & 0.672 \\ \text { ABELHAS } & 0.639 \\ \text { Abelha } & 0.367 \\ \text { Abelha europa } & 0.156 \\ \text { Mamangá } & 0.083 \\ \text { Abelha que agarra no cabelo } & 0.050 \\ \text { Abelha mamangava } & 0.033 \\ \text { Besouro mamangá } & 0.031 \\ \text { Abelha preta } & 0.017 \\ \text { Abelha jataí } & 0.011\end{array}$

0.017

0.017

$\begin{array}{cl}\text { OUTROS INSETOS } & 0.050 \\ \text { Vespa } & 0.033 \\ \text { Besourinho } & 0.017 \\ & 0.200\end{array}$

after the flowering period, and the peak season is between December and January for certain regions of Minas Gerais (Leite et al., 2006). The time of Pequi flowering and fruiting varies according to abiotic factors and is mainly associated with temperature, humidity, and the rainy season (Oliveira and Scariot, 2010). Flowering occurs early in the dry season along with the fall of most of the leaves from June to October (Oliveira, 2009; Oliveira and Scariot, 2010).

The occurrence of occasional Pequi fruits was mentioned by $93 \%$ of respondents $(n=28)$, and it refers to the irregular and unpredictable behavior of several trees that blossom and bear fruit outside of the expected time, generally occurring from June to August. The interviewees indicated that variations in rainfall and temperature are the environmental factors that influence the appearance of occasional fruits. Such occasional harvests also occur in the municipality of Itumirim, southern Minas Gerais, although there is a much lower abundance of fruit in the months of July and August compared with that of the normal harvest season (Oliveira, 2009).

Biannual fruit yield cycles with major and minor crops were also mentioned by respondents, and the intensity and frequency of rainfall were indicated as the major factors responsible for higher productivity. Alternating productivity of $C$. brasiliense between years has been reported in the State of Goiás by Santana and Naves (2003), in Minas Gerais by Oliveira (2009), and in the Federal District by Zardo and Henriques (2011), and such productivity is generally associated with flutuations in rainfall. According to Pontinha respondents, the time required for a Pequi tree to begin fruiting is 3 to 20 years, which is the time required to reach a height between 2.5 and $5.0 \mathrm{~m}$. The Pequi tree can require up to 28 years before it begins producing fruits; however, with proper care, this time can be reduced to 8 years (Oliveira, 2009).

The occurrence of disease or parasites in Pequi trees was mentioned in $37 \%$ of the interviews $(n=11)$ and included pests that bore into older trees, caterpillars that eat the leaves or stem and root, leaves that turn purple, and the bird herb and "vigueira" that fatally invade the roots inside the Pequi tree. The caterpillar belonging to the family Cossidae (Lepidoptera) is recognized as a borer into the C. brasiliense trunk (Leite et al., 2011), and the fungal species Colletotrichum acutatum causes the disease anthracnose on Pequi leaves (Anjos et al., 2002). One respondent claimed that it was rare for Pequi to become sick because "Pequi is a healthy tree."

Regarding the Pequi fruit, "caterpillar holes" or "caterpillars that rot the fruit" and "fungi" were the most frequently reported damage; "beetles" and "black spots" in the shell were also mentioned. Caterpillars of the genus Carmenta cause the fruit to drop prematurely, which renders the fruits unsuitable for consumption (Lopes et al., 2003). The predation rate of seeds (inner mesocarp) by lepidopteran recorded by Oliveira (2009) is approximately $5 \%$. The author observed that, during flowering, butterfly larvae cause losses of more than $50 \%$ of the crop production. However, Oliveira (2009) also added that ants live in Pequi 
Table 2. Values of cultural consensus (S) for the frugivores of the Pequi tree (Caryocar brasiliense) that eat unfallen fruit and fallen fruit on the ground as cited by respondents from the Pontinha community, Minas Gerais.

\begin{tabular}{|c|c|c|c|c|}
\hline & Common name & Folk name & S (unfallen fruit) & S (fallen fruit) \\
\hline \multirow[t]{16}{*}{ BIRDS } & & & 0.359 & 0.259 \\
\hline & Magpie & Pêga/gralha & 0.167 & 0.067 \\
\hline & Parrot & Papagaio & 0.146 & 0,077 \\
\hline & Parrot & Maritaca & 0.126 & 0.033 \\
\hline & Passerine & Passarinho & 0.067 & 0.050 \\
\hline & Toucan & Tucano & 0.039 & 0.008 \\
\hline & New World Jays & Gralha & 0.033 & 0.033 \\
\hline & Parakeet & Periquito & 0.023 & 0.017 \\
\hline & Parakeet & Periquito maracanã & 0.011 & - \\
\hline & Chicken & Galinha & - & 0.033 \\
\hline & Dove & Juriti & - & 0.033 \\
\hline & Sparrow & Pardal & - & 0.033 \\
\hline & Guan & Jacu & - & 0.027 \\
\hline & Hornero & João-de-barro & - & 0.022 \\
\hline & Pigeon & Verdadeira & - & 0.020 \\
\hline & Ruddy Ground Dove & Rolinha & - & 0.011 \\
\hline \multirow[t]{8}{*}{ INSECTS } & & & 0.067 & 0.574 \\
\hline & Beetle & Besouro & 0.033 & 0.023 \\
\hline & Caterpillar & Lagarta & 0.033 & - \\
\hline & Ant & Formiga & - & 0.527 \\
\hline & Bee & Abelha & - & 0.033 \\
\hline & Larva & Larvas & - & 0.033 \\
\hline & Termite & Cupim & - & 0.029 \\
\hline & Borer & $\begin{array}{c}\text { Bicho que apodrece } \\
\text { o fruto }\end{array}$ & - & 0.017 \\
\hline \multirow[t]{7}{*}{ MAMMALS } & & MAMÍFEROS & 0.138 & 0.123 \\
\hline & Bat & Morcego & 0.138 & 0.019 \\
\hline & Marmoset & Sagui & 0.033 & - \\
\hline & Armadillo & Tatu & - & 0.067 \\
\hline & Humans & Pessoas & - & 0.033 \\
\hline & Maned Wolf & Lobo & - & 0.020 \\
\hline & Opossum & Gambá & - & 0.017 \\
\hline DO NOT EXIST & & & 0.067 & 0.033 \\
\hline DO NOT KNOW & & & 0.400 & 0.133 \\
\hline
\end{tabular}

trees and work as guardians, protecting the tree against butterflies and other insects.

Most of the respondents perceived a negative influence of fire on the adults or young individuals of $C$. brasiliense. According to them, young and mature individuals were the most adversely affected by fire, which was also observed by Oliveira (2009), because fire compromises the trees' growth and reproduction and may lead to death. Although Pequi can resist fire events that are not intense (Medeiros and Miranda, 2005), the mortality rate, according to Whelan (1995), is higher in smaller individuals, which can be attributed to certain traits of younger individuals, such as a thinner bark, as noted in the interviews. Medeiros and Miranda (2005) point out that the diameter of the individual is the determining factor for the species survival in Cerrado fire events and smaller and shorter plants can survive if the stem diameter is greater.

\section{Conclusion}

The "quilombola" community of Pontinha has broad ecological knowledge regarding $C$. brasiliense as well as the importance of this species for local use besides its potential as a source of alternative income. Local knowledge 
about Pequi supplements the information available in the literature. This fact reinforces the importance of ethnoecological research associated with population ecology and socioeconomics studies. Such complementarity will support the viability analysis of the wider use of Pequi by Pontinha's community, especially when the "minhocuçus" extractive activity is reduced.

Given the process of socio-cultural and economic changes ongoing in the region of this study, understanding the traditional knowledge is fundamentally important for constructing a management proposal for the Pequi and for maintaining the Cerrado's environmental services.

Furthermore, in future management plans of $C$. brasiliense, the effects of climate change on the fruit productivity and other direct threats (such as land use changes and burning) to the Cerrado vegetation should be considered, in addition to the impacts of increased extraction.

\section{Acknowledgements}

We thank the Pró-Reitorias de Extensão (ProEx) and Pesquisa (PRPq) from Universidade Federal de Minas Gerais and Programa de Pós Graduação em Ecologia, Conservação e Manejo da Vida Silvestre. We are also grateful to the Programa de Extensão Universitária do Ministério da Educação (PROEXT MEC-2013) and Fundação de Amparo à Pesquisa do Estado de Minas Gerais (FAPEMIG) for the financial support and Floresta Nacional de Paraopeba for the logistical support. Special appreciation is extended to the Pontinha community for participating in this study.

\section{References}

ADAMS, C., CHAMLIAN MUNARI, L., VAN VLIET, N., SERENI MURRIETA, R.S., PIPERATA, B.A., FUTEMMA, C., NOVAES PEDROSO, N., SANTOS TAQUEDA, C., ABRAHÃO CREVELARO, M. and SPRESSOLA-PRADO, V.L., 2013. Diversifying incomes and losing landscape complexity in Quilombola shifting cultivation communities of the atlantic rainforest (Brazil). Human Ecology, vol. 41, no. 1, pp. 119-137. http://dx.doi.org/10.1007/s10745-012-9529-9.

AFONSO, S.R. and ÂNGELO, H., 2009. Mercado de produtos florestais não madeiros do cerrado brasileiro. Ciência Florestal, vol. 19, no. 3, pp. 315-326. http://dx.doi.org/10.5902/19805098887.

ALBUQUERQUE, U.P., 1999. Referências para o estudo da etnobotânica dos descendentes culturais do africano no Brasil. Acta Farma Bonaerense, vol. 18, no. 4, pp. 299-306.

ALBUQUERQUE, U.P., LUCENA, R.F.P. and ALENCAR, N., 2010. Métodos e técnicas para coleta de dados etnobiológicos. In: U.P. ALBUQUERQUE, R.F.P. LUCENA and N. ALENCAR, eds. Métodos e técnicas na pesquisa etnobotânica e etnoecológica. Recife: NUPEEA, pp. 41-64.

ALMADA, E.D., 2012. Entre as Serras: etnoecologia de duas comunidades quilombolas no sudeste brasileiro. Campinas: Universidade Estadual de Campinas, 257 p. PhD Thesis.

ANJOS, J.R.N., CHARCHAR, M.J.A. and AKIMOTO, A.K., 2002. Ocorrência de antracnose causada por Colletotrichum acutatum em pequizeiro no Distrito Federal. Fitopatologia
Brasileira, vol. 27, no. 1, pp. 96-98. http://dx.doi.org/10.1590/ S0100-41582002000100016.

AQUINO, L.P., BORGES, S.V., QUEIROZ, F., ANTONIASSI, R. and CIRILLO, M.A., 2011. Extraction of oil from pequi fruit (Caryocar Brasiliense, Camb.) using several solvents and their mixtures. Grasas y Aceites, vol. 62, no. 3, pp. 245-252. http:// dx.doi.org/10.3989/gya.091010.

ARAUJO, F.D., 1995. A review of Caryocar brasiliense (Caryocaraceae): an economically valuable species of the central brazilian cerrados. Economic Botany, vol. 49, no. 1, pp. 40-48. http://dx.doi.org/10.1007/BF02862276.

ASSUNÇÃO, P.E.V., 2012. Extrativismo e comercialização de pequi (Caryocar brasiliense Camb.) em duas cidades no estado de Goiás. Revista Economica, vol. 8, no. 2, pp. 17-26.

BAILEY, K., 2008. Methods of social research. 4th ed. New York: The Free Pass. 588 p.

BARBOSA, A.S., RIBEIRO, M.B. and SCHMITZ, P.I., 1990. Cultura e ambiente em áreas do sudoeste de Goiás. In: M.N. PINTO, ed. Cerrado caracterização, ocupação e perspectivas. Brasília: Universidade de Brasília, pp. 67-100.

BARROSO, R.M., REIS, A. and HANAZAKI, N., 2010. Etnoecologia e etnobotânica da palmeira juçara (Euterpe edulis Martius) em comunidades quilombolas do Vale do Ribeira, São Paulo. Acta Botanica Brasílica, vol. 24, no. 2, pp. 518-528. http:// dx.doi.org/10.1590/S0102-33062010000200022.

BERKES, F., COLDING, J. and FOLKE, C., 2000. Rediscovery of traditional ecological knowledge as adaptive management. Ecological Applications, vol. 10, no. 5, pp. 1251-1262. http:// dx.doi.org/10.1890/1051-0761(2000)010[1251:ROTEKA]2.0.CO;2 .

BERNARD, H.R., 1988. Research methods in cultural anthropology. Newbury Park: Sage Publications. 520 p.

BERNARD, H.R., 2006. Research methods in anthropology. 4th ed. Oxford: Altamira Press. 803 p.

BONFÁ, H.C., RUFINO, L.M.A., RIBEIRO-JUNIOR, C.S., MORAIS, G., GERASSEV, L.C. and RIBEIRO, F.L.A., 2009. Efeitos dos níveis de inclusão do farelo da casca de pequi sobre a digestibilidade aparente em caprinos. In: Anais do Congresso Brasileiro de Zootecnia, 2009, Águas de Lindóia. Águas de Lindóia: Associação Brasileira de Zootecnista.

BRASIL. Ministério do Meio Ambiente-MMA. Núcleo dos Biomas Cerrado e Pantanal, 2004. Programa Nacional de Conservação e Uso Sustentável do Bioma Cerrado. Brasília. 67 p.

CARVALHO, P.E.R., 2008. Espécies arbóreas brasileiras. Brasília: Embrapa Informação Tecnológica. 593 p.

CEZARI, E.J., 2010. Plantas medicinais: atividade antitumoral do extrato bruto de sete plantas do cerrado e o uso por povos tradicionais. Tocantins: Universidade Federal do Tocantins, 49 p. Masters Dissertation.

CREPALDI, M.O.S. and PEIXOTO, A.L., 2010. Use and knowledge of plants by Quilombolas as subsidies for conservation efforts in an area of Atlantic Forest in Espírito Santo State, Brazil. Biodiversity and Conservation, vol. 19, no. 1, pp. 37-60. http:// dx.doi.org/10.1007/s10531-009-9700-9.

DIEGUES, A.C. and VIANA, V.M., 2004. Comunidades tradicionais e manejo dos recursos naturais da Mata Atlântica. São Paulo: Hucitec. 273 p. 
DONOVAN, D.G. and PURI, R.K., 2004. Learning from traditional knowledge of non-timber forest products: Penan Benalui and the autecology of Aquilaria in Indonesian Borneo. Ecology and Society, vol. 9, no. 3, pp. 383-391.

DRUMOND, M.A., GUIMARÃES, A. and GIOVANETTI, L., 2009. Técnicas e ferramentas participativas para a Gestão de Unidades de Conservação. Brasília: Ministério do Meio Ambiente, Programa Áreas Protegidas da Amazônia. 120 p.

DRUMOND, M.A., GUIMARÃES, A.Q., EL BIZRI, H.R., GIOVANETTI, L.C., SEPÚLVEDA, D.G. and MARTINS, R.P., 2013. Life history, distribution and abundance of the giant earthworm Rhinodrilus alatus RIGHI 1971: conservation and management implications. Brazilian Journal of Biology $=$ Revista Brasileira de Biologia, vol. 73, no. 4, pp. 699-708. http://dx.doi. org/10.1590/S1519-69842013000400004. PMid:24789384.

FIGUEIREDO, I.B., SCHMIDT, I.B. and SAMPAIO, M.B., 2006. Manejo sustentável de capim-dourado e buriti no Jalapão, TO: importância do envolvimento de múltiplos atores. In: R.R. KUBO, J.B. BASSI, C.G. SOUZA, N.L. ALENCAR, P.M. MEDEIROS and U.P. ALBUQUERQUE, eds. Atualidades em Etnobiologia e Etnoecologia. 1st ed. Recife: NUPEEA/Sociedade Brasileira de Etnobiologia e Etnoecologia, vol. 3, pp. 101-114.

FRANCO, E.A.P. and BARROS, R.F.M., 2006. Use and diversity of medicinal plants at the "Quilombo Olho D'água dos Pires", Esperantina, Piaui State, Brazil. Revista Brasileira de Plantas Medicinais, vol. 8, no. 3, pp. 78-88.

GALUPPO, S.C., 2004. Documentação do uso e da valorização do óleo do Piquiá (Caryocar villosum) e do leite do Amapá-doce (Brosimum parinarioides) para a Comunidade de Piquiatuba, Floresta Nacional do Tapajós: estudos físicos, químicos, fitoquímicos efamacológicos. Belém: Universidade Federal Rural da Amazônia, 108 p. Masters Dissertation.

GERMANO, J.N., SILVA, R.L.A. and SANTOS, E.M., 2007. Estudo etnobotânico das plantas medicinais do cerrado do estado de Mato Grosso. Revista Brasileira de Plantas Medicinais, vol. 3 , no. 1, pp. 23-31.

GONÇALVES, C.U., 2008. Os pequizeiros da Chapada do Araripe. Revista de Geografia., vol. 25, no. 1, pp. 88-103.

GRIBEL, R., 1986. Ecologia da polinização e da dispersão de Caryocar brasiliense Camb. (Caryocaraceae) na região do Distrito Federal. Brasília: Universidade de Brasília, 109 p. Masters Dissertation.

HANAZAKI, N., 2003. Comunidades, conservação e manejo: o papel do conhecimento ecológico local. Biotemas., vol. 16, no. 1 , pp. 23-47.

LEITE, G.L.D., ALVES, S.M., NASCIMENTO, A.F., LOPES, P.S.N., FERREIRA, P.S.F.F. and ZANUNCIO, J.C., 2011. Identification of the wood-borer and the factors affecting its attack on Caryocar brasiliense trees in the Brazilian Savanna. Acta Scientiarum: Agronomy, vol. 33, no. 4, pp. 589-596. http:// dx.doi.org/10.4025/actasciagron.v33i4.8629.

LEITE, G.L.D., VELOSO, R.V.D.S., ZANUNCIO, J.C., FERNANDES, L.A. and ALMEIDA, C.I.M., 2006. Phenology of Caryocar brasiliense in Brazilian Cerrado region. Forest Ecology and Management, vol. 236, no. 2-3, pp. 286-294. http://dx.doi. org/10.1016/j.foreco.2006.09.013.

LIMA, I.L.P., 2008. Etnobotânica quantitativa de plantas do Cerrado e extrativismo de mangaba (Hancornia speciosa Gomes) no Norte de Minas Gerais: implicações para o manejo sustentável. Brasília: Universidade de Brasília, 106 p. Masters Dissertation.

LIMA, I.L.P., SCARIOT, A., MEDEIROS, M.B. and SEVILHA, A.C., 2012. Diversidade e uso de plantas do Cerrado em comunidade de Geraizeiros no norte do Estado de Minas Gerais, Brasil. Acta Botanica Brasilica, vol. 26, no. 3, pp. 675-684. http://dx.doi. org/10.1590/S0102-33062012000300017.

LOPES, P.S.N., SOUZA, J.C., REIS, P.R., OLIVEIRA, J.M. and ROCHA, I.D.F., 2003. Caracterização do ataque da broca dos frutos do pequizeiro. Revista Brasileira de Fruticultura, vol. 25 , no. 3, pp. 540-543. http://dx.doi.org/10.1590/S010029452003000300046 .

MASSAROTTO, N.P., 2009. Diversidade e uso de plantas medicinais por comunidades quilombolas Kalunga e urbanas no nordeste do estado de Goiás-GO, Brasil. Brasília: Universidade de Brasília, 140 p. Masters Dissertation.

MEDEIROS, H. and AMORIM, A.M.A., 2015 [viewed 20 January 2015]. Caryocaraceae. In: JARDIM BOTÂNICO DO RIO DE JANEIRO - JBRJ. Lista de espécies da flora do Brasil [online]. Rio de Janeiro: JBRJ. Available from: http://floradobrasil.jbrj. gov.br/jabot/floradobrasil/FB6688

MEDEIROS, M.B. and MIRANDA, H.S., 2005. Mortalidade pós-fogo em espécies lenhosas de campo sujo submetido a três queimadas prescritas anuais. Acta Botanica Brasílica, vol. 19, no. 3, pp. 493-500. http://dx.doi.org/10.1590/S0102-33062005000300009.

MELO, C., 2001. Diurnal bird visiting of Caryocar brasiliense, Camb in central Brazil. Brazilian Journal of Biology $=$ Revista Brasileira de Biologia, vol. 61, no. 2, pp. 311-316. http://dx.doi. org/10.1590/S0034-71082001000200014. PMid:11514899.

MITTERMEIER, R.A., GIL, P.R., HOFFMAN, M., PILGRIM, J., BROOKS, T., MITTERMEIER, C.G., LAMOREUX, J. and FONSECA, G.A.B., 2004. Hotspots revisited. Mexico: Cemex. $392 \mathrm{p}$.

MONTELES, R. and PINHEIRO, C.U.B., 2007. Plantas medicinais em um quilombo maranhense: uma perspectiva etnobotânica. Revista de Biologia e Ciências da Terra, vol. 7, no. 2, pp. 1-11.

MORAIS, F.F. and SILVA, C.J., 2010. Conhecimento ecológico tradicional sobre frutiferas para pesca na Comunidade de Estirão Comprido, Barão de Melgaço - Pantanal Matogrossense. Biota Neotropica, vol. 10, no. 3, pp. 198-203.

MORAIS, L.M.O., PINTO, L.C.L., GUIMARÃES, A.Q. and DRUMOND, M.A., 2013. Conhecimento ecológico tradicional sobre o pequi e outros frutos do Cerrado de interesse comercial no quilombo de Pontinha - Paraopeba/MG. In: Anais do VI Seminário Brasileiro sobre Áreas Protegidas e Inclusão Social (VI SAPIS) e I Encontro Latinoamericano sobre Áreas Protegidas e Inclusão Social (I ELAPIS), 2013, Belo Horizonte. Belo Horizonte: UFMG, vol. 6 , no. $1.1049 \mathrm{p}$

OLIVEIRA, D.R., COSTA, A.L.M.A., LEITÃO, G.G., CASTRO, N.G., SANTOS, J.P. and LEITÃO, S.G., 2011. Estudo etnofarmacognóstico da saracuramirá (Ampelozizyphus amazonicus Ducke), uma planta medicinal usada por comunidades quilombolas do Município de Oriximiná-PA, Brasil. Acta Amazonica, vol. 41, no. 3, pp. 383-392. http://dx.doi.org/10.1590/S0044-59672011000300008.

OLIVEIRA, M.E.B., GUERRA, N.B., BARROS, L.M. and ALVES, R.E., 2008. Aspectos agronômicos e de qualidade do pequi. Fortaleza: Embrapa Agroindústria Tropical. 32 p. Documentos, no. 113. 
OLIVEIRA, W.L. and SCARIOT, A., 2010. Boas práticas de manejo para o extrativismo sustentável do pequi. Brasília: Embrapa Recursos Genéticos e Biotecnologia. 84 p.

OLIVEIRA, W.L., 2009. Ecologia populacional e extrativismo de frutos de Caryocar brasiliense no Cerrado no norte de Minas Gerais. Brasília: Universidade de Brasília, 82 p. Masters Dissertation.

PEDROSO-JÚNIOR, N.N. and SATO, M., 2005. Ethnoecology and conservation in protected natural areas: incorporating local knowledge in Superagui National Park management. Brazilian Journal of Biology = Revista Brasileira de Biologia, vol. 65, no. 1, pp. 117-127. http://dx.doi.org/10.1590/S1519-69842005000100016. PMid:16025911.

PIANOVSKI, A.R., VILELA, A.F.G., SILVA, A.A.S., LIMA, C.G., SILVA, K.K., CARVALHO, V.F.M., MUSIS, C.R., MACHADO, S.R.P. and FERRARI, M., 2008. Uso do óleo de pequi (Caryocar brasiliense) em emulsões cosméticas: desenvolvimento e avaliação da estabilidade física. Revista Brasileira de Ciências Farmacêuticas, vol. 44, no. 2, pp. 249-259.

POZO, O.V.C., 1997. O pequi (Caryocar brasiliense): uma alternativa para o desenvolvimento sustentável do cerrado no Norte de Minas Gerais. Lavras: Universidade Federal de Lavras, 100 p. Masters Dissertation.

PURI, R.K. and VOGL, C.R., 2005. A methods manual for ethnobiological research and cultural domain analysis: with analysis using ANTHROPAC. Canterbury: Department of Anthropology, University of Kent. 72 p.

RATTER, J., 1997. The Brazilian Cerrado vegetation and threats to its biodiversity. Annals of Botany, vol. 80, no. 3, pp. 223-230. http://dx.doi.org/10.1006/anbo.1997.0469.

RIOS, M., MARTINS-DA-SILVA, R.C.V., SABOGAL, C., MARTINS, J., SILVA, R.N., BRITO, R.R., BRITO, I.M., BRITO, M.F.C., SILVA, J.R. and RIBEIRO, R.T., 2001. Beneficios das plantas da capoeira para a comunidade de Benjamin Constant, Pará, Amazônia Brasileira. Belém: CIFOR. 54 p.

RODRIGUES, V E.G. and CARVALHO, D.A., 2001. Levantamento etnobotânico de plantas medicinais no domínio do cerrado na região do Alto Rio Grande, Minas Gerais. Ciência e Agrotecnologia, vol. 25 , no. 1, pp. 102-123.

ROESLER, R., CATHARINO, R.R., MALTA, L.G., EBERLIN, M.N. and PASTORE, G., 2008. Antioxidant activity of Caryocar brasiliense (pequi) and characterization of components by electrospray ionization mass spectrometry. Food Chemistry, vol. 110, no. 3, pp. 711-717. http://dx.doi.org/10.1016/j.foodchem.2008.02.048.

SABARÁ, R., 2001. Comunidade Negra Rural de Pontinha: agonia de um modo de produção. Belo Horizonte. mimeo.
SANO, S.M., ALMEIDA, S.P. and RIBEIRO, J.F., 2008. Cerrado: ecologia e flora. Brasília: EMBRAPA. 1279 p. Informação Tecnológica, vol. 1.

SANTANA, J.C. and NAVES, R.V., 2003. Caracterização de ambientes de cerrado com alta densidade de pequizeiros. Pesquisa Agropecuária Tropical, vol. 33, no. 1, pp. 1-10.

SANTOS, F.S., SANTOS, R.F., DIAS, P.P., ZANÃO-JUNIOR, L.A. and TOMASSONI, F., 2013. A cultura do Pequi (Caryocar brasiliense Camb.). Acta Iguazu, vol. 2, no. 3, pp. 46-57.

SARAIVA, R.A., ARARUNA, M.K.A., OLIVEIRA, R.C., MENEZES, K.D.P., LEITE, G.O., KERNTOPF, M.R., COSTA, J.G.M., ROCHA, J.B.T., TOMÉ, A.R., CAMPOS, A.R. and MENEZES, I.R.A., 2011. Topical anti-inflammatory effect of Caryocar coriaceum Wittm.(Caryocaraceae) fruit pulp fixed oil on mice ear edema induced by different irritant agents. Journal of Ethnopharmacology, vol. 136, no. 3, pp. 504-510. http://dx.doi. org/10.1016/j.jep.2010.07.002. PMid:20621180.

SCHMIDT, I.B., FIGUEIREDO, I.B. and SCARIOT, A., 2007. Ethnobotany and effects of harvesting on the population ecology of Syngonanthus nitens (Bong.) Ruhland (Eriocaulaceae), from Jalapão region, central Brazil. Economic Botany, vol. 61, no. 1, pp. 73-85. http://dx.doi.org/10.1663/0013-0001(2007)61[73:EA $\mathrm{EOHO}] 2.0 . \mathrm{CO} ; 2$.

SILVA, M.N.S. and TUBALDINI, M.A.S., 2013. O ouro do cerrado: a dinâmica do extrativismo do pequi no norte de Minas Gerais. Revista Geoaraguaia, vol. 3, no. 2, pp. 293-317.

SOUSA JÚNIOR, J.R., ALBUQUERQUE, U.P. and PERONI, N., 2013. Traditional Knowledge and Management of Caryocar coriaceum Wittm. (Pequi) in the Brazilian Savanna, Northeastern Brazil. Economic Botany, vol. 67, no. 3, pp. 225-233. http://dx.doi. org/10.1007/s12231-013-9241-8.

VIANA, R.V.R., 2013. Diálogos possiveis entre saberes cientificos e locais associados ao capim-dourado e ao buriti na região do Jalapão, TO. São Paulo: Universidade de São Paulo, 92 p. Masters Dissertation.

VIEIRA, R.F., COSTA, T.S.A., SILVA, D.B., FERREIRA, F.R. and SANO, S.M., 2006. Frutas nativas da região centro-oeste. Brasília: Embrapa Recursos Genéticos e Biotecnologia. 320 p.

WHELAN, R.J., 1995. The ecology of fire. Cambridge: Cambridge University Press. 346 p.

ZARDO, R.N. and HENRIQUES, R.P.B., 2011. Growth and fruit production of the tree Caryocar brasiliense in the Cerrado of central Brazil. Agroforestry Systems, vol. 82, no. 1, pp. 15-23. http://dx.doi.org/10.1007/s10457-011-9380-9. 